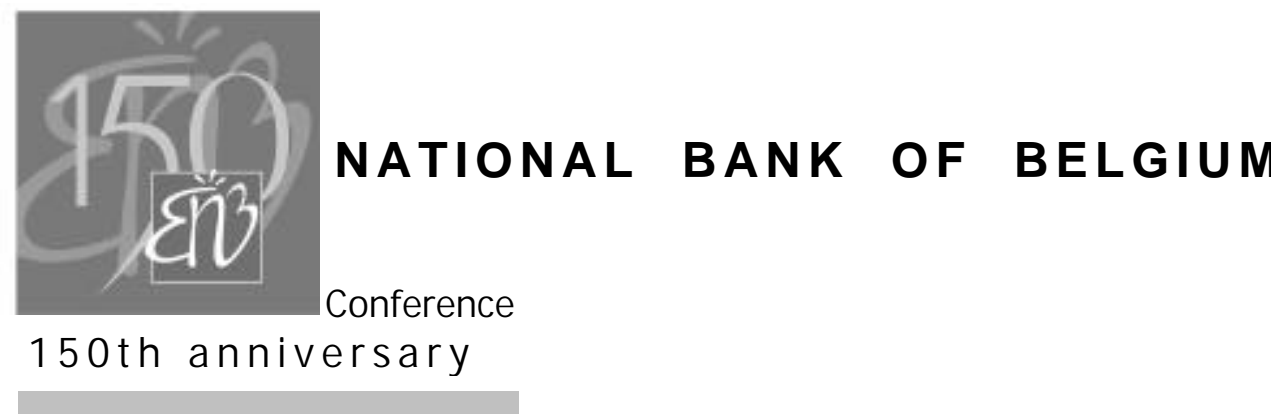

WORKING PAPERS - RESEARCH SERIES

\title{
FISCAL POLICY AND GROWTH IN THE CONTEXT OF EUROPEAN INTEGRATION
}

\author{
Paul Masson ${ }^{(*)}$ \\ Brookings Institution and International Monetary Fund
}

I am grateful to Tam Bayoumi for helpful discussions, to Susan Becker and Nicholas Dopuch for providing data, and to Jungyon Shin for excellent research assistance. The paper has benefited from comments received from colleagues in the IMF's European I department, but the views expressed are those of the author and do not represent those of any official institution. 


\section{Editorial Director}

Jan Smets, Member of the Board of Directors of the National Bank of Belgium

\section{Statement of purpose:}

The purpose of these working papers is to promote the circulation of research results (Research Series) and analytical studies (Documents Series) made within the National Bank of Belgium or presented by outside economists in seminars, conferences and colloquia organised by the Bank. The aim is thereby to provide a platform for discussion. The opinions are strictly those of the authors and do not necessarily reflect the views of the National Bank of Belgium.

The Working Papers are available on the website of the Bank:

http://www.nbb.be

Individual copies are also available on request to:

NATIONAL BANK OF BELGIUM

Documentation Service

boulevard de Berlaimont 14

B - 1000 Brussels

Imprint: Responsibility according to the Belgian law: Jean Hilgers, Member of the Board of Directors, National Bank of Belgium. Copyright $\odot$ National Bank of Belgium

Reproduction for educational and non-commercial purposes is permitted provided that the source is acknowledged.

ISSN: .1375-680X 


\title{
Editorial
}

On May 11-12, 2000 the National Bank of Belgium hosted a Conference on "How to promote economic growth in the euro area?". A number of papers presented at the conference is made available to a broader audience in the Working Papers series of the Bank. This volume contains the third of these papers. The other five papers were issued as Working Papers 5-6 and 8-10.

\begin{abstract}
The paper considers the issue of whether a supranational fiscal policy in Europe is needed, and, if so what responsibilities it should undertake. The literature on endogenous growth and the principle of subsidiarity suggest that such a policy should be limited to externalities or economies of scale not captured at the national level. These may include spending on research and development and transportation or knowledge networks, and harmonization of social security designed to enhance labor mobility. EU-wide stabilization policy or enhanced EU redistribution does not seem justified, however.
\end{abstract}




\section{TABLE OF CONTENTS:}

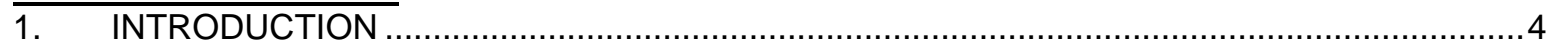

2. THE CONTEXT FOR FISCAL POLICIES IN THE EUROPEAN UNION …................................

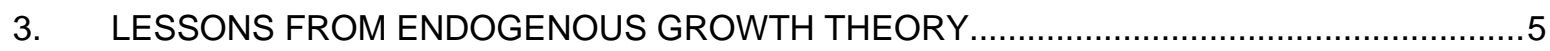

4. COMPETITION VERSUS COORDINATION .....................................................................

5. DOES COORDINATION REQUIRE A FEDERAL FISCAL POLICY ? ................................12

6. IN WHAT AREAS SHOULD A EUROPEAN FISCAL POLICY OPERATE ? ..........................15

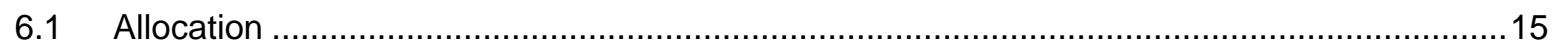

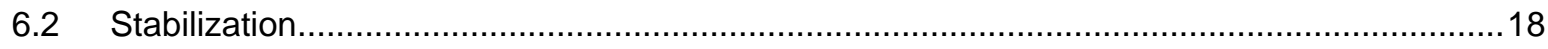

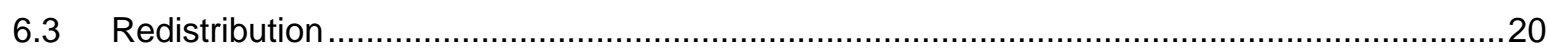

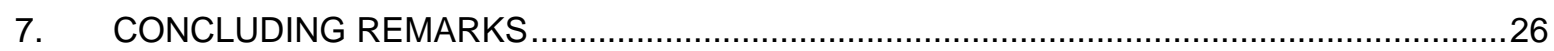

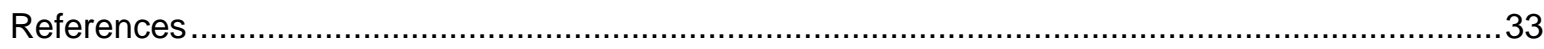




\section{INTRODUCTION}

Much has already been written about the possible evolution of fiscal policy in Europe in the light of the formation of a monetary union. The creation of the euro in January 1, 1999, the subsequent implementation of a common monetary policy by the ECB, and the coming into force of the Stability and Growth Pact for the countries in euroland have created a new immediacy for the issue. In this paper, the design of fiscal policy will be discussed from the perspective of long-term growth of the euro area. The focus is on whether an expanded European fiscal policy is desirable, or even perhaps essential, from that perspective. The design of fiscal institutions can have potentially large effects, for good or ill, on economic performance. Less attention will be given to the desirable orientation of national or subnational fiscal policies. The growth perspective is dictated by the focus of the conference, rather than by a conviction that maximizing growth is the same thing as maximizing welfare.

There would seem to be three central questions that need to be answered when forming a judgement about the design of European ${ }^{1}$ fiscal policy. First, is greater coordination of fiscal policies needed in the context of a monetary union? To some extent, EU countries have already answered yes to this question, and the provisions of the Maastricht Treaty on excessive deficits and the Stability and Growth Pact are the result. However, the issue remains whether the system will work adequately without further changes. Second, if greater coordination in some form is needed, can it be achieved through greater harmonization and inter-governmental coordination or will it require some form of fiscal federalism, as implemented by nation states such as the United States, Germany, or Canada, among others? And third, aside from the above institutional questions, are there good economic reasons why greater power at the European supranational level would be good for economic growth, and, if so, in what areas would European fiscal policy have a comparative advantage? These reasons might include externalities that can be best exploited at the European level, such as those related to knowledge networks, subsidies to innovation, etc.

"European" will be used as a shorthand for "among the countries of the euro area. 
It is obvious that to reach a view about the desirability of one or another design of European fiscal institutions requires examining a broad set of factors that extend well beyond narrow positive economic analysis. Concern about loss of economic sovereignty may dominate considerations of economic efficiency. Alternatively, the desire to enhance individuals' economic freedom may result in a distrust of bureaucracies and resistance to any extension of the power of governments ${ }^{2}$ And the extent that a strong sense of European solidarity emerges may dictate whether European redistribution through fiscal policies develops. So this paper will not attempt to reach a definitive view or pretend to treat all the important questions. Instead, it will consider whether economic analysis, especially the new literature on endogenous growth, has interesting things to say about the desirable evolution of European fiscal policy. Obviously also relevant are the literatures on fiscal federalism (e.g. Oates, 1972; Walsh, 1993) and economic policy coordination (e.g. Bryant, 1995), though neither is based on models of endogenous growth.

It is argued below that given the size of national government spending in Europe, there is no scope for additional fiscal policy involvement of European institutions. Moreover, a clear implication of the principle of subsidiarity is that European fiscal policy should be limited to correcting distortions or exploiting externalities that cannot be corrected or exploited by national fiscal policies. One such externality is tax competition, but this may best be addressed by government agreements to harmonize tax rates or coordinate their collection. When considering government investment spending, the EU budget should be limited to those items where the EU-wide (social) rate of return exceeds the national returns. Where externalities do not extend across national boundaries, or can be appropriated by countries raising taxes or imposing user fees, then they should not be the responsibility of EU institutions.

The paper first sets the stage for considering an EU-wide fiscal policy by putting the role of government in EU countries into perspective relative to other industrial countries. It then briefly reviews endogenous growth theory before examining the case for fiscal policy coordination and how to achieve it. The specific areas where a European fiscal policy might be desirable are discussed, focussing on the allocative, stabilization, and redistributive roles of fiscal policy. This is followed by a concluding section.

Disagreements on this point, rather than on economic analysis, explain differences in the positions of James Buchanan and Richard Musgrave on European integration (Buchanan and Musgrave, 1999). 


\section{THE CONTEXT FOR FISCAL POLICIES IN THE EUROPEAN UNION}

Any consideration of EU fiscal policies must acknowledge that the starting point is one in which European countries stand out as having an extraordinarily high level of government services and taxation, relative to other industrial countries and even more so, relative to poorer countries. Some macroeconomic data are presented in Table 1; aside from Ireland and the United Kingdom, virtually all of the EU countries have substantially higher levels of government spending and taxation than the non-European industrial countries. The higher involvement of EU governments concerns mainly a larger amount of spending on redistribution, especially social security systems.

High levels of spending in Europe emerged in the early postwar period as an element of social consensus between employers and unions. Indeed, generous unemployment insurance and health schemes have been administered jointly by the "social partners" in several EU countries. While this high level of redistribution has no doubt had a favorable impact on social cohesion and has smoothed labor relations, the associated rigidity has increasingly been seen to have costs. High social contributions by employers and generous unemployment benefits have discouraged employment, and the rise in unemployment further increased the extent of redistribution, creating a vicious circle. Health care costs have risen rapidly as public insurance has permitted excessive use of some services. As a result of the ageing of the population, generous pay-as-you-go pension plans increasingly have had to face the choice of raising contributions or reducing benefits, especially since public plans in several countries permitted early retirement in sectors (coal, steel, shipbuilding) hit by high unemployment as the result of loss of competitiveness or adverse demand shifts.

The evident budgetary and efficiency costs of some social programs have led to an attempt to roll back the role (and cost) of government, but the process has proved difficult and contentious, and countries have been successful to varying extents. The United Kingdom and Denmark, for instance, have substantially reduced publicly provided pension benefits in favor of private, funded retirement plans, and the Netherlands has moved away from centralized labor negotiations and substantially reduced disability benefits. Other countries (such as Belgium, France, and Spain) have liberalized part-time work in order to increase flexibility, as well as reducing social charges for the lower paid, where the employment disincentives were greatest. Nevertheless, as Table 1 shows, there remains a large gap between the typical EU country and the other industrial 
countries in terms of the size of government spending. While empirical evidence is not uncontroversial, it seems hard to deny that the disappointing output and employment growth in some European countries during the last few decades is due in part to the rigidities resulting from a large public sector and generous social programs. Evidence summarized in Crafts (2000) suggests that OECD countries, especially those in Europe, have passed the point where the favorable effects of government spending on growth are offset by the disincentive effects of taxes. Therefore, the design of a European fiscal policy must be considered in a context where a further decline in the role of government would in many cases be desirable, rather than any expansion. This makes the case for an EU-wide fiscal policy doubly hard to make, since it needs to be accompanied by suggested areas for reduction in national responsibilities.

Turning to the current size of the EU budget, Table 2 shows that spending commitments, at 97 billion euros in 1999, are very modest as a proportion of EU GDPonly some 1.25 percent. Aside from agricultural expenditures, which make up about half of the budget, spending is mainly on transfers to poorer regions (structural operations), and to a much more limited extent on administrative expenditures, external action, and research subsidies. Revenues are accounted for primarily by GNP-based contributions from member states and the EU's share of VAT revenues. Customs duties are relatively small, given the trend decline in tariff rates. 


\section{LESSONS FROM ENDOGENOUS GROWTH THEORY}

The endogenous growth literature suggests many avenues for government intervention to affect growth (see Aghion and Howitt, 1998; also the survey of fiscal policy and growth in a broader context by Tanzi and Zee, 1997). The neoclassical theories of economic growth (e.g. Solow, 1956) took technical progress to be exogenous, and longrun growth was determined by it and population growth. Economic policy, such as policies to stimulate saving or to tax the returns to investment, could affect the level of per capita income but not its growth rate. Newer models with the rate of technical progress endogenous in principle imply much more powerful effects of fiscal policy, because they can permanently increase the growth rate of output ${ }^{3}$

At a very general level, tax or subsidy policies that encourage investment can raise the growth rate in endogenous growth models, provided the social rate of return on investment exceeds the private return (Barro and Sala-i-Martin, 1992). A higher social return may be the result of externalities; for instance, the accumulation of knowledge may benefit not just the individual but also the society as a whole. Innovations may produce the base for further innovation, with the original innovator unable to appropriate all the profits. Or "learning by doing" may increase the skill level of the whole economy (and not just the firm undertaking production). In these circumstances, social returns may exceed private returns.

While this paper cannot attempt to survey the endogenous growth literature ${ }^{4}$, a brief review of the main strands is in order, since they have somewhat different implications. The first main strand is what is known as AK models ${ }^{5}$, in which each individual firm $\mathrm{j}$ faces a traditional Cobb-Douglas production function with exogenous technology factor $B: Y_{j}=B K_{j}^{a} L_{j}^{1-a}$. However, the level of knowledge in the economy as a whole depends on the aggregate capital stock; it is assumed that the technology parameter increases with the economy-wide capital labor ratio, $B=A(K / L)^{b}$, where $\mathrm{K}=\sum \mathrm{K}_{\mathrm{j}}$ and $\mathrm{L}=\sum \mathrm{L}_{\mathrm{j}}$. If the further assumption is made that $\mathrm{a}+\mathrm{b}=1$, then the aggregate production function becomes $\mathrm{Y}=\mathrm{AK}$. In this model, the firm does not internalize the effect

\footnotetext{
However, Harris (1996) points out that for most relevant planning horizons, level effects and growth rate effects are indistinguishable, and that the former could be comparable to the latter in magnitude.

4 See Aghion and Howitt (1998) and a paper by Stephen Turnovsky prepared for this conference.

Developed by Frankel (1962) and popularized by Romer (1986) and Lucas (1988).
} 
that its investment has in increasing economy-wide knowledge, so investment is too low. There is therefore a role for fiscal policy to subsidize investment and thereby increase growth and welfare. Unlike in neoclassical growth models, in which capital accumulation can proceed too far and generate "dynamic inefficiency," more capital accumulation can never reduce per capita consumption in this model (though there is a limit to which a social planner would like to sacrifice current consumption in order to invest and produce more future consumption). The AK model thus has a clear policy implication for government policy, but the model does not contain the richness of detail that would allow it to make predictions concerning the type of investment or the sectors that should be favored.

A second strand of endogenous growth models is much richer in that it distinguishes between capital accumulation and innovation, that is the creation of new goods or goods of improved quality. In these models, technological progress corresponds to an increase in the number of different types of capital goods (the "variety model"), or the creation of new capital goods of higher quality (the "quality ladder model") ${ }^{6}$ The latter models have been termed "Schumpeterian," because they build on the insight from Joseph Schumpeter that innovation involves "creative destruction." Thus, a new innovation makes obsolete earlier products or techniques.

An example of such a model is given in Aghion and Howitt (1998, chapter 2). It abstracts from capital accumulation; instead, output of the consumption good depends on the input of an intermediate good $x$ as follows:

$$
y=A x^{a}
$$

Labor can serve to produce either innovations (i.e. be devoted to research, in amount $n$ ) or the intermediate goods $x$ that go into the production of consumer goods; one unit of labor is required to produce each $x$. The economy's total stock of labor is equal to $L$, so

$$
\mathrm{L}=\mathrm{x}+\mathrm{n}
$$

Labor devoted to research produces innovations but with a lapse of time that is stochastic, based on a Poisson process, where the mean arrival rate is $\lambda \mathrm{n}$. An innovation increases the technology parameter by the constant factor $\gamma$, so

$$
A_{t+1}=\gamma A_{t}
$$

where here $t$ refers to the time innovations occur, not fixed intervals. Innovators can monopolize the intermediate goods sector until replaced by the next innovator, but there are positive spillovers that are reflected in growth in A: the monopoly rents earned by the

6 See Grossman and Helpman (1991). 
innovator are less than the consumer surplus created by the intermediate good, and the invention makes it possible for other researchers to work on the next innovation. An arbitrage condition determines the amount of labor devoted to the two uses, research and production, so that expected profits from the two are equalized.

In this model, the benefits of increased knowledge do not accrue entirely to the firm or individual realizing the innovation. Lack of complete appropriability combined with an intertemporal externality resulting from the fact that current innovations allow future innovations to build on them (with monopoly profits accruing to other innovators) suggests that privately determined $R \& D$ investment will be too low. However, this neglects the fact that an innovation produces a loss to society that is not internalized by the research firm, because it makes products by other firms obsolete. This is termed the "business-stealing effect" by Aghion and Howitt (1998). Thus the net effect on R\&D investment relative to its optimal level is ambiguous. It may not be the case that investment is too low from a welfare standpoint.

Though innovations can be embodied in new capital equipment, they need not be, as the above model shows. In more complicated models, technological progress can have several possible sources. Primary innovation can result from R\&D investment, while secondary innovation can involve embodying primary innovations in specific capital goods. Another channel for endogenous growth is the accumulation of human capital, which enhances the productivity of labor. Human capital can increase because of formal education or from "learning by doing."

Because of the richness of endogenous growth models, it is difficult to summarize any general conclusions from them for fiscal policy, aside from the desirability of stimulating productive activities or investment in areas where the social return is greater than the private return. At a minimum, it suggests that subsidies to research, if they are targeted, should be directed to areas where the externalities of increased knowledge are greatest, and where the ability of private firms to appropriate the benefits is small (for instance, in pure rather than applied research, and in fields where patent protection may be less effective). The success of targeting, however, depends on how much information officials have. A better alternative may be to "let the market decide" and provide untargeted subsidies to whatever firms take them up, or to set up private sector boards for 
allocating funds ${ }^{7}$ But the way technological change impacts the economy is crucial. Knowledge may not result just from research but also from "learning by doing". If "learning by doing" produces benefits that are largely external to firms (increasing the general level of skills for the economy as a whole), then this type of knowledge accumulation could be too low relative to pure research. So blanket subsidies to pure research (shifting resources out of the productive sector) may not be good for growth. Multi-product models where goods are produced with different technologies and by workers with different skill levels suggest that growth may also be increased, in an environment of continual innovation, by increased mobility or adaptability of the work force (Lucas, 1993; Aghion and Howitt, 1998, chapter 6). Such models suggest that fiscal policy needs to focus on education and flexibility-enhancing training.

Unlike the neoclassical growth models, in which growth is divorced from cyclical fluctuations, the new endogenous growth models integrate, to a greater or lesser extent, the two phenomena. In particular, Schumpeterian models can explain economic downturns as the result of the technological innovations that produce long-term growth. Though the above model based on Aghion and Howitt (1998), chapter 2, does not produce recessions, a slightly more complicated model with two stages of innovations is capable of doing so (Helpman and Trajtenberg, 1994). Suppose that the first stage is devoted to discovering a general-purpose technology (GPT), but that this does not increase output until it is embodied in an intermediate good, which requires a second stage of innovation. Since research involves the use of productive resources (labor), during the time between the arrival of a new GPT and the discovery of a way of embodying it into an intermediate good, aggregate output goes down. More complicated dynamics are possible in models where the stages of innovation exceed two and where there are knowledge spillovers in adapting to the new technology.

The general implication of such models is that creative destruction accompanying innovation, by making existing technologies obsolete and requiring a sectoral reallocation of other factors (primarily labor), may in the short run produce recessions even though in the longer run it contributes to higher output. Indeed, following Schumpeter a case can be made that recessions are in fact good for growth, because they allow weeding out of less productive firms, or force reorganizations to make firms more efficient, allowing them to survive. A somewhat different reason for not being concerned with recessions is that output may be mismeasured in the presence of innovation, because the national accounts

The advantages and disadvantages of each are discussed in Aghion and Howitt (1998, chapter 14). 
do not capture the future productivity involved in increases in knowledge (unlike those in capital equipment, which show up in investment). The links between cyclical fluctuations and growth are explored more fully below, when considering implications for stabilization policy.

Endogenous growth models also permit a more satisfactory consideration of fiscal redistribution policy than is possible in neoclassical models, where it is assumed that there is a basic tradeoff is between greater equity and the lower efficiency associated with redistribution. In endogenous growth models, redistribution need not be harmful to growth, nor greater inequality be the result of the growth process, as was argued (for an intermediate range of income levels) by Kuznets. Political economy reasons may produce higher growth if redistribution, by reducing inequality, weakens entrenched interests and eliminates social conflicts (Benabou, 1996), while if the poor are credit constrained, redistribution may improve their productivity (Aghion et al., 1999).

If the scope for productive fiscal policies to stimulate long-run growth is enhanced by endogenous growth models, the potentially negative effects of distorting taxes are also greater. Rather than simply affecting the level of output, taxes may have permanent growth rate effects by discouraging accumulation of the relevant factor or discouraging innovation. Thus, the case for specific government policies needs to be balanced carefully against the potential growth rate reductions due to the taxes that are raised to finance the expenditures. Moreover, the nature of the public goods produced by governments should influence optimal tax policy. Barro and Sala-i-Martin (1992) argue that many public goods are subject to congestion, and hence are rival but to some extent non-excludable. In these circumstances, they should be financed by income taxation, which operates like a user fee, rather than by lump-sum taxation.

Empirical studies of the effect of different tax structures on long-term growth are few, given the difficulties in getting detailed cross-country data on tax rates. One of the few studies, Mendoza et al. (1997), finds some confirmation of Harberger's conjecture that tax policy has little effect on long-run growth. Though the mix of direct and indirect taxes is in theory an important determinant, in practice plausible changes in tax rates are unlikely to affect growth to an economically significant extent, even if they have a reasonably large effect on investment. 


\section{COMPETITION VERSUS COORDINATION}

The case for coordination of fiscal policies within the European Union is based on two principal arguments. First, with greater integration among EU countries (including especially greater factor mobility), tax competition may lead to a reduction in tax rates, thus limiting the scope for financing (except by benefit taxation) otherwise desirable fiscal spending at the national level. Coordination of tax policies (in particular, harmonization on a high enough rate that government tax revenues are not adversely affected) would be a possible response. Alternatively, if there are efficiency gains from a common tax administration, there would be a case for levying EU-wide taxes, and either moving some spending to the EU-wide level, or instituting a system of transfers of revenue from the EU to national governments.

The second argument for coordination of fiscal policies lies with externalities that cause uncoordinated policies to be suboptimal. In general terms, this may occur if the benefits of public goods extend across national borders, if there are increasing returns to scale in the provision of public goods, or if there are macroeconomic spillovers from fiscal policies. Possible externalities and efficiency gains from public goods are discussed below, so here we focus on macroeconomic spillovers.

The excessive deficit procedure of the Maastricht Treaty and the Stability and Growth Pact are based on a concern that independently chosen fiscal policies would be too expansionary (because, for instance, of electoral cycles leading policymakers to have short horizons and high discount rates), and would thereby endanger the price stability objective of the common monetary policy. This fear may also add to uncertainty, which may lower investment and harm growth. Hence some way of tying the hands of governments and threatening sanctions if they exceed a deficit threshold is judged to be desirable. The periodic occurrence of government solvency crises suggests that this fear has some objective reality. Though there has been considerable debate about the extent to which the market would be able to discipline national fiscal policies, and about whether the no-bailout clause of the ECB is sufficient in itself to prevent negative spillovers of errant national policies, in any case a decision has been taken to proceed with constraints on national fiscal policies.

But there are other reasons why uncoordinated fiscal policies (even if constrained not to exceed limits on deficits) may be suboptimal. Cohen and Wyplosz (1989) argue that 
since countries in monetary union share the same real exchange rate with the rest of the world, they will each be led to overexpansionary policies in response to asymmetric shocks, but insufficiently expansionary policies in response to a symmetric, but transitory, supply shock. In contrast, coordinated policies would be designed to optimally incorporate the shared effect of the monetary area's trade balance on the real exchange rate.

The experience of existing federal systems helps to shed some light on the importance both of tax competition and lack of coordination of government spending policies. Subnational governments in both the United States and Canada exhibit continuing substantial differences in tax rates on personal income and goods and services, perhaps because relative prices adjust, including the price of land (Tiebout, 1956). It could be argued that the remaining pressure toward low taxes resulting from competition is a salutary force, helping to keep governments honest by providing some choices to citizens (Buchanan in Buchanan and Musgrave, 1999, chapter 3). However, in specific areas the absence of either coordination among U.S. states or federal programs has prevented the creation of arguably welfare-improving policies, for instance universal health care in the United States. Tanzi (2000) has argued that increasing globalization will lead to a widespread cutback and redesign of social protection. There is a legitimate concern that increasing mobility will lead to limits on social security programs in Europe, though some would argue that this is a good thing. In the absence of a consensus across Europe about the desirable features of social security, it may be difficult to achieve enough harmonization to prevent competition toward the bottom from operating. This would jeopardize the ability of those countries wanting to operate more generous programs than the average, and might even lead to a spiral downward to levels that no country would consider first-best.

Turning to spending policies, though U.S. states have little scope for discretionary fiscal policies, in Canada the provinces have greater fiscal powers and have at times had substantial budgetary imbalances. In particular, during the 1980s, provinces faced different cyclical positions, and Ontario's expansionary policies no doubt contributed to an appreciated real exchange rate that added to the recessionary forces affecting other regions (Courchene, 1993). Thus there does seem to be some reason to expect that lack of coordination could cause problems within Europe, especially as a result of the larger countries' fiscal policies. 


\section{DOES COORDINATION REQUIRE A FEDERAL FISCAL POLICY?}

If one takes as given that greater coordination of fiscal policies may be desirable in Europe, what form should it take? There would seem to be three general models of how to achieve it. First, countries could agree to harmonize their tax and expenditure policies. For instance, in the area of social security there could be an agreement on common tax rates and benefit levels (leaving aside for the moment different tax capacities in different countries). Enforcing such agreements might be difficult without some European-wide institutional involvement: in federations, this is usually achieved through shared-cost programs, in which the junior governments have a financial incentive to go along with the federal government standards. Already, there is a considerable degree of harmonization of VAT rates and administration. Attempts at harmonization of taxes on investment income have been a notable failure, and there has been little coordination, much less harmonization, of social policies.

Second, the governments could agree to a common program administered by the relevant European institutions. If an important program were involved, e.g. social security, then going down this road would involve moving a considerable way toward a system of fiscal federalism, with all the emotive responses that such a prospect stimulates. The enforcement mechanism mentioned above (shared cost programs) would however already be a step in that direction.

Third, coordination could involve intergovernmental surveillance over national fiscal policies, but no binding constraints on the exercise of national sovereignty (aside from possible sanctions from running excessive deficits) nor significant development of an EU budget. In this model, coordination would result from peer pressure, but, as in global policymaking (e.g. G-7 policy coordination), there would be nothing to ensure that governments would act any differently than they would if they set policies in an uncoordinated way. Moreover, the G-7 experience has involved only episodic coordination, at best. The only possible difference might be that the closeness of EU government relationships in a number of areas could reinforce the effectiveness of peer pressure.

Which model eventually prevails will be determined in the political arena, and economic considerations will be only one, and perhaps not the most important, consideration. Nevertheless, there are some observations that can be made about the 
various institutional alternatives. First, though a clear enunciation of the institutional setup at an early stage would be desirable (as suggested by James Buchanan in Buchanan and Musgrave, 1999, p. 202), this is unlikely to happen. Instead, institutions will evolve over time, as a result of struggles between competing bureaucracies or initiatives by political leaders, with public opinion also influencing the process. At any point in time, the system will reflect all three models: in some areas there will be harmonization, in others surveillance and peer pressure, and in still others, some elements of fiscal federalism. Even nations with constitutions and laws setting up the responsibilities of various institutions see long periods before a degree of stability and a clear vision of respective roles are defined. The experience of the U.S. Federal Reserve System, reviewed by Eichengreen (1992), is a case in point. Furthermore, the context for the operation of fiscal policy in the euro area will evolve, perhaps drastically, with the admission of new members and possibly as a result of structural changes caused by greater economic integration. For instance, the common use of the euro will facilitate transactions, lead to consolidation of financial systems, and perhaps help produce greater labor mobility. The rationale for a common fiscal policy may be considerably stronger in ten or twenty years as a result.

Second, there is likely to be a tradeoff between the flexibility of the arrangements chosen and the ability to eliminate beggar-thy-neighbor behavior. Fully optimal policies (absent problems of time consistency, à la Barro-Gordon), would allow the fiscal policy to be tailored to each shock, and reflect aggregate welfare; by the definition in the theoretical literature, this is the coordinated solution. The optimal policy is unlikely to be described by a simple, easily monitored, policy rule, hence, in practice, there is no guarantee that in any given circumstance coordination can be achieved, and the optimal policies chosen. Alternatives to such flexible coordination include harmonization or common EU-wide programs. Neither is likely to be fully optimal, because based on a "one-size fits all" approach. However, such arrangements may be more likely to guarantee that some form of coordination will occur that rules out the worst outcomes.

Finally, one can question whether monetary integration can survive without tighter political integration. As pointed out, for instance, by Goodhart (1996), EMU as currently constituted is a unique enterprise - the creation of a currency without a sovereign behind it, in the sense of a government exercising all the traditional powers of nation-states. This situation might make the monetary union fragile. For instance, if circumstances facing one of the members of monetary union go seriously awry, can the union persist without some financial assistance by the others? If not, will some sort of national safety net be 
institutionalized to provide the assistance? Similarly, will pressures for portability of social benefits and integration of tax systems become overwhelming once the freedom to move within the EU (as guaranteed by the Single Market program) is fully exploited? While the answers to these questions are not unambiguous, they nevertheless point in the direction of stronger EU-wide institutions, including for fiscal policy. 


\section{IN WHAT AREAS SHOULD A EUROPEAN FISCAL POLICY OPERATE ?}

It is useful when considering this question to discuss in turn the traditional functions of fiscal policy, grouped into its allocative, stabilization, and redistributive roles. Starting from the principle of subsidiarity, the case for EU-wide fiscal policies must rely on the existence of externalities or distortions which cannot be captured or corrected at the national level.

\subsection{Allocation}

The main categories of spending where social returns may exceed private returns would seem to consist in spending on education, public infrastructure, and R\&D. Such spending can have externalities that are not captured in private decisionmaking so that there is a potential role for government spending in these areas to help increase long-run growth $^{8}$. To what extent should this be done at the supra-national, rather than national, level? The criterion for these activities should be that the (social) return to the EU is greater than the national return. Otherwise, national governments would already have the proper incentives to optimally subsidize activities where the return to the country exceeded private returns.

The activity of education would not seem to involve significant externalities that go beyond national borders ${ }^{9}$. Indeed, education is often the responsibility of regional or local governments within countries, whether they be unitary states or federations. The case for a common national (or supranational) policy is usually based on redistributive arguments: residents of those regions that are too poor to meet a common standard should not suffer the loss of opportunities that inferior education would imply. With the European Union consisting of countries with roughly similar per capita incomes, or at least prosperous enough to offer adequate education, the case for commonly financed education is not compelling.

\footnotetext{
8 The growth literature does not give very specific guidance, however. Aschauer (1989) found large returns from government infrastructure investment, which have been questioned by other economists. Barro (1991) reported regessions in which growth was negatively related to government consumption expenditures, but not to public investment, which had little relationship with growth. De Long and Summers (1991) found that the social rate of return to equipment investment was 30 percent per year or higher, and argued that government policy should be designed to stimulate it. Mansfield (1996) surveys studies that found that R\&D in several industries had social returns far in excess of their private returns.

9 Education per se needs to be distinguished from the research that is performed at institutions of higher learning, which is likely to have spillovers, and also from the stock of human capital individuals accumulate as a result of education, and which may involve externalities. As a result of the latter, education spending in one country may benefit other countries if there is migration.
} 
Turning to infrastructure investment, national governments in Europe are already heavily involved in this area. Indeed, over the past two decades many governments have concluded that some of the activities performed in the public sector could best be privatized. Thus, infrastructure investments in water distribution, telecommunications, electricity generation, and rail and air transportation are increasingly likely to be carried out by private firms, not government enterprises. In this context, European-wide government projects should not roll back the clock toward more government intervention, with its now widely recognized inefficiencies. The case for a greater European role rests on the existence of unexploited profitable opportunities, whose benefits extend beyond the individual country undertaking the investment. For instance, a highway might benefit neighboring countries, even if the residents of the country concerned would use it little. Or an information network might have favorable effects that could only be fully captured at a supranational level. Under this reasoning, EU fiscal policy should be involved in truly "European" projects, rather than competing with the projects that national governments already did. Identifying such projects with Europe-wide externalities is not straightforward, however. In the example of a highway, levying a toll on users would allow the national government to capture the externality, and eliminate the need for a European initiative; that is, it is a "pecuniary externality" that does not require coordination. It may be that for "information superhighways" the ability to appropriate benefits is much more limited, especially at early developmental stages, making a pan-European investment attractive.

EU financing of research and development would seem desirable in principle since the benefits of increased knowledge are unlikely to accrue purely at the national leve $\left.\right|^{10}$. Already, the EU has a modest budget to finance research projects in a number of areas, and in nuclear energy EU-wide funding of research centers (CERN) has a long history. European externalities are more likely at the pure research level, rather than at the stage of commercial exploitation. For the latter, joint ventures are likely to be arranged, or collaborative efforts involving national government subsidies (Airbus, Eurofighter, etc.) which do not involve EU institutions.

10 However, Acs et al. (1996) argue that in Canada the "network dynamics" relevant for innovation are local or regional, rather than national, and Bottazzi and Peri (1999) find that spatial spillovers from one European region on another within $200 \mathrm{~km}$. are statistically significant, but not large. 
Another reason for EU involvement in funding research and development is that there are spillovers from national policies ${ }^{11}$. In particular, the "business-stealing" effect also operates across national borders, so that national subsidies to a particular high-tech sector may be self-defeating if all countries engage in it. Instead, coordination of R\&D policies would allow for more efficient allocation of resources. For the same reason that strategic trade policy is not possible in a free trade area, and responsibility for trade policy transferred to EU institutions, at least some role in research and development policy properly resides with community institutions. Indeed, state aids to industry in the EU have been greatly reduced and are subject to EU Commission oversight.

How the public sector can best stimulate innovation and capture externalities is not a simple question, however. Lipsey and Carlaw (1996) survey 30 cases of government involvement in producing and commercializing innovations. They conclude that attempting large technological leaps (Concorde, British gas-cooled nuclear reactors, Japanese 5th generation computer project, among others) often are dangerous, because they are likely to fail at great public expense, as are overriding private sector preferences on the course of the innovation process, picking "national champions" and aiming at national prestige. Government bureaucracies are not notably well suited for picking winners, though they may serve to coordinate companies involved in innovation in the same area and facilitate information spillovers. One could question whether direct involvement of bureaucrats in the selection and financing of projects is the appropriate model for the EU. More appealing is making available research grants or loans at attractive terms, the beneficiaries of which are chosen by peer review rather than guided by the bureaucracy. Applied research would then be the province of the private sector.

The recommendations of Mansfield (1996) go in this direction. Noting that government, by subsidizing inappropriately, could do more harm than good even if social returns in principle exceeded private ones, Mansfield formulates five guidelines. First, government programs should be small-scale probes using parallel approaches, and aim to stimulate R\&D in the private sector. Second, political pressures to focus on beleaguered industries should be resisted. Third, the government should not get involved in the later stages of development work. Fourth, when involved in stimulating research in civilian technology the government should ensure proper coupling with the market; the private

11 The nature of those spillovers depends on the type of policy (e.g. subsidies for fundamental research, or to the production of high tech goods), on whether innovation is best described by the varieties model or the quality ladder model, and on whether research and development involves developing cutting-edge techniques or imitating and refining other innovations. See Grossman and Helpman (1991), chapters 10-12. 
sector should have a role in project selection. Fifth, given the fundamental uncertainty of the R\&D process, governments should recognize the advantages of pluralism and decentralized decision making.

\subsection{Stabilization}

The argument has been made that EMU has increased the need for fiscal stabilization, because it has eliminated the scope for national monetary policies to perform this function. At the same time, the Stability and Growth Pact has placed strong constraints on fiscal policies, in particular providing for sanctions of up to 0.5 percent of GDP should a government's deficit exceed 3 percent of GDP. This will limit the possibility for fiscal stabilization, should a country suffer an unfavorable shock when it is already running a deficit close to the ceiling. A common unemployment insurance system has been advocated, given constraints on national stabilization policies, because it would create an automatic stabilizer operating at the EU level ${ }^{12}$.

However, evidence presented in Bayoumi and Masson (1996) suggests that national governments in the EU were able in the past to perform as much fiscal stabilization as is done in monetary unions such as the United States or Canada, so that the need for more stabilization after the creation of EMU is not obvious ${ }^{13}$. Though the efficiency of performing stabilization at the EU level might well be greater than for national stabilization policies, because an EU-wide system would involve some redistribution in the case of asymmetric shocks, and would thus not be subject to the same Ricardian offsets (Bayoumi and Masson, 1998), the fundamental question is whether stabilization policy is actually necessary or desirable.

While stabilization policy (e.g. operating through unemployment compensation) may have welfare-improving effects if there are distortions that prevent instantaneously achieving market-clearing wages and prices, the effects of stabilization policy on growth are not clear cut. Traditional growth theory would suggest that there should be no growth rate effects of stabilization, since fluctuations would be independent of the exogenous factors driving long-term growth. However, newer theories provide a linkage between the

12 See Mélitz and Vori (1992) and Pisani-Ferry, Italianer, and Lescure (1993). Von Hagen and Hammond (1997) argue that an effective system would not involve large net transfers, but would be very complex and hence difficult to implement, while simpler schemes would not be very effective.

13 Fatás and Mihov (1999) present evidence for OECD countries that the greater the size of government spending relative to GDP, the lower the volatility of output. EU countries have high government spending ratios when compared to other industrial countries (or indeed to developing countries). However, as we will see below lower volatility of output is positively correlated with lower growth. 
two. On the one hand, stabilization policy may reduce uncertainty by cushioning shocks, and there is some evidence concerning the negative effects of uncertainty on investment and growth (e.g. Easterly and Rebelo, 1993). Of course, if fluctuations are predictable, it is not correct to equate business cycles with uncertainty. On the other hand, a new literature related to the Schumpeterian notion of "creative destruction" suggests that allowing economic downturns to weed out inefficient enterprises may actually be good for growth (Aghion and Howitt, 1998, chapter 8). Therefore, stabilization policy could be harmful for growth if it reduced the necessary restructuring that should accompany technical progress. Indeed, positive technology shocks may initially be associated with economic downturns, as resources are reallocated to their most productive uses. To the extent that fluctuations are driven by "general purpose technology" shocks (see above), government policy should not resist the restructuring process, though it may want to cushion the worst effects on individuals, e.g. on those thrown out of work. Depending on which view is taken about the effects of stabilization policy on growth, the limits embodied in the Stability Pact may or may not be cause for concern.

A simple correlation across EU countries between the average growth rate of real GDP and its standard deviation is significantly positive, and equal to about 0.5 , not negative as the above argument would suggest, but positive shocks to GDP could be expected to increase both, so no causality is implied (Table 3). A more interesting exercise is to relate the strength of stabilization policy to the growth rate of output. A simple measure of stabilization policy is the slope coefficient in a regression of the deficit ratio on the output gap ${ }^{14}$. A larger (positive) coefficient would indicate a greater use of counter-cyclical stabilization policy. A benchmark case would be if all revenues varied proportionately with GDP, but all expenditures were fixed: if initially both revenues and expenditures are equal to 50 percent of GDP (as is roughly the case for EU countries), then the slope coefficient should be 0.5 , since the deficit would increase in a downturn by the decline in revenues, with no change in expenditure ${ }^{15}$. In order to correct for simultaneity due to the stabilizing effects on output of the deficit, instrumental variables are used, which tends to reduce the positive relationship among the variables. Nevertheless,

\footnotetext{
14 The output gap is calculated simply by dividing actual real GDP by smoothed GDP, the latter calculated using a HodrickPrescott filter with lambda $=1000$.

15 The empirical evidence suggests that while most industrial countries undertake some form of countercyclical fiscal policy, in developing countries fiscal policy is typically procyclical. Talvi and Végh (2000) explain this stylized fact by appeal to the incentives to increase spending resulting from budget surpluses in developing countries.
} 
12 countries out of 15 have a positive slope ( 8 of which are significant at the 10 percent level); details of the regressions are reported in the Appendix. The estimates suggest that Denmark, Sweden, Portugal, and Finland engage in the most stabilization, with coefficients well in excess of 0.5. Two of these, Denmark and Sweden, have also experienced slow growth in the last 3 or 4 decades. At the opposite extreme are Greece, Ireland, and Italy, with no stabilization, and relatively high growth ${ }^{16}$. Interestingly enough, if the slope coefficients are correlated with average GDP growth, the correlation coefficient is strongly negative, and equal to about -0.55 , which is significant at the 5 percent level. While not a substitute for serious econometric testing, this suggests that stabilization may be harmful to growth, consistent with a Schumpeterian model. Thus from the perspective solely of growth, limits on the ability to perform stabilization policy would not seem to be cause for concern. Of course, the reason for adopting automatic stabilizers, for instance unemployment insurance, is not necessarily related to growth, since such policies may be motivated primarily by welfare objectives. Moreover, stabilization policy may be desirable to control booms (for instance to limit inflationary pressures), while this phase of stabilization would not be subject to the objection that it was limiting creative destruction.

\subsection{Redistribution}

Conventional wisdom says that redistribution policy is bad for growth because of negative incentive effects. A new literature (Aghion et al., 1999; Aghion and Howitt, 1998, chapter 9) suggests that redistribution may in fact be good, if there are capital market distortions that prevent resources going to their most productive uses (it is assumed that the marginal product of the poor is higher than that of the rich, because their existing level of capital in productive activities is lower). In these circumstances, redistribution favors growth because it allows the poor to accumulate capital, for instance working capital to start a business. A slightly different argument has to do with ensuring minimum levels of public goods and services that are thought to promote growth (Kollintzas et al., 1999). Because of different levels of per capita income, regional or local governments may not be able to provide those services at similar tax rates, and higher tax rates in poorer regions or localities will provide incentives for the more mobile, and presumably better educated, to leave, impeding income convergence. Equalization of fiscal capacity is the explicit justification for redistribution among provinces as carried out by the Canadian fiscal system (see Courchene, 1993).

16 Coefficients are negative but insignificant. Negative coefficients that are insignificantly different from zero may result from the existence of a large debt stock over at least some of the period, which implies that much of the fiscal position is accounted for by debt service, not cyclical considerations. 
There is a large amount of redistribution within EMU countries, especially when compared to the United States or the United Kingdom. Table 4 presents data on social protection spending for EU countries. It can be seen that the set of countries where the ratio to GDP is above 30 percent in 1996 includes the nordic countries and most of the original members of the EEC, while many countries on the "periphery" including newer non-nordic members have ratios well below 30 percent. It is interesting to correlate growth with social benefits, though clearly one needs a longer period than would be possible using 1996 data, and caution is needed in interpreting the results. Different types of social spending may have different effects (e.g. pensions vs. unemployment benefits) and the methods of financing (e.g. social contributions vs. VAT) may also affect the estimated relationship. In order to avoid the effects of lower growth on increased social benefits, initial values of the latter (as ratios to GDP) are correlated with subsequent GDP growth ${ }^{17}$. Social benefits data are only available on a comparable basis for all EU countries starting in 1993, giving only a short period for evaluating growth, so various subsets of countries are examined over time periods dictated by data availability.

The results suggest no support for the new view that redistribution is favorable to growth. Admittedly, the negative correlation declines as more countries (but a shorter subsequent growth period) are included. More detailed measures of redistribution are possible, and they are likely to have different effects. A larger sample, including some non-EU countries, might allow greater confidence in the results. But on the face of it, the traditional view of a tradeoff between equity and growth, at least in Europe, is not contradicted.

Though redistribution is pervasive within EU countries, across Europe (e.g. between countries), there is little redistribution. Extending the theoretical argument made above that redistribution would favor growth at this level is even harder to make convincingly. While individuals may well face capital market imperfections, which prevent the poor from borrowing to finance productive investment, to make a case for intergovernmental redistribution one must also show that governments are constrained in their attempts to carry out redistribution or to make productive infrastructure investments. EMU countries now face generally well developed access to international capital markets.

17 There is still a potential problem of reversed causation if poorer countries can only afford lower levels of social protection, but grow faster as they converge to per capita income levels of the rest of the EU. This would suggest controlling also for the initial level of income, but paucity of observations made this difficult. Following Temple (1999), we have also not included traditional regressors (e.g. investment/GDP ratios), because of their pervasive endogeneity, preferring to focus directly on policy variables. 
EMU, by creating a single capital market, has increased the access to financing by governments (as evidenced by data on narrowing spreads) and corporations (creation of a euro Commercial Paper and junk bond markets). Davis (1998) argues that the combination of the single currency and a move toward funded pensions will lead to substantial financial deepening in Europe. So national governments should be able to perform redistribution among their populations or provide domestic infrastructure without the need for a supranational institution.

There are two other arguments for redistribution across countries. First, because of different per capita income levels, tax capacity varies, meaning that to provide similar social services, governments will need to have different tax rates, leading to migration. Migration is inefficient if it serves only to arbitrage differences in net fiscal benefits, because it involves resource costs (transportation, basic services, housing construction). Some redistribution may therefore be optimal from this perspective (see Boadway, 1996). Second, redistribution can have the purpose of facilitating solidarity among EU member countries and fostering public support for greater integration. If the latter is good for growth (as would be suggested by the experience of countries such as Greece, Ireland, Portugal, and Spain since joining the EU), the modest amount of redistribution involved in Structural and Cohesion Funds may be justified from a growth perspective.

However, the case for enhanced EU redistribution does not seem particularly compelling from these two perspectives. The problem in the EU is not too much factor mobility, but too little. The experience of regional redistribution suggests that it contributes to factor immobility (in particular, by limiting the incentives for migration between regions) and the latter is likely to be inimical to growth. For instance, labor mobility contributes to the spread of knowledge and enhances the knowledge externality, as well as allowing factors to be employed in their most productive uses. Automatic transfers may reduce the incentives for countries to make needed structural reforms (Persson and Tabellini, 1996). The pitfalls of systematic regional redistribution could be illustrated in the Canadian and Italian contexts. For instance, Courchene (1993) talks of "welfare dependency" of the poorer Canadian provinces (i.e. the Maritimes), which have persistently benefited from federal equalization payments. As for the solidarity argument, the reduction in per capita income differences that have occurred within the EU suggest that increased inter-country transfers are not needed. 
I would argue that the strongest case for a European social security policy is not to achieve redistribution across national borders in order to allow the poor access to productive opportunities or for poorer governments to provide necessary infrastructure, but rather to standardize benefits to facilitate labor mobility. Social security systems differ considerably across EU countries. Table 5 illustrates the extent of variation in public pension spending, replacement ratios of public pension programs, and the extent of private pension funds. Not surprisingly, the latter two are negatively correlated. Lack of portability and standardization of pension benefits can be a barrier to mobility across borders in Europe (Dantec and Pelgrin, 1998).

There is already an emerging consensus that the generosity of PAYG pension plans needs to be cut back, though whether they would be partially replaced by fully funded plans is still contentious (Boldrin et al., 1999). The latter would facilitate labor mobility, if provisions of the various plans are standardized and their portability is ensured by legislation. Otherwise, they will further impede mobility. The transition away from PAYG plans toward funding will in any case be difficult to achieve fully, especially in the context of a demographic transition that reduces the number of contributors to beneficiaries (Miles and Timmermann, 1999). The mostly likely solution is not the elimination of public PAYG plans, but rather the coexistence of reduced benefits provided by PAYG plans with an expansion of funded plans. If this process of pension reform proceeds, social security programs could be redefined so that some benefits were portable across countries, helping to encourage mobility, rather than contributing to immobility. It will be important to make the basic pension levels similar, and to enforce portability of funded pensions. If this is done, qualifying years of service for pensions could be earned in any EU country, and the unemployed could be allowed to draw benefits while moving to another country or region where they judged the prospects of finding a job were better.

How could pension reform best be achieved in the EU, so as to facilitate labor mobility ? Some have argued that there is no case for involvement of EU institutions, that the issue can be handled by intergovernmental agreements (Dantec and Pelgrin, 1998). However, effectively removing barriers to mobility presupposes a high degree of harmonization of social security policies, and its implementation would cause problems of administration if not done centrally. In practice, the required degree of coordination may not be possible if left to national authorities, and the task would be simplified by a common, EU-wide social security system that was run, or at least guided, by EU institutions, possibly through shared-cost programs. Vansteenkiste (1998) advocates a clear division of 
competencies between the EU and national governments (as in a federal system), which he views as necessary in the area of social security in order to make progress in coordinating and harmonizing policies. He argues that the EU should have primary responsibility for "income replacement" schemes (unemployment benefits, pensions, income support), and the national governments for "cost compensating" schemes (medical care, child allowances). Such a radical proposal would be difficult to implement in one step, Pieters and Vansteenkiste (1993) had earlier proposed that a new, EU-run, social insurance scheme be introduced just for migrants between EU countries. Such a scheme would provide an element of competition for national social security programs that would tend to harmonize them, but not produce excessive reduction of benefits.

If the current public pension plans are replaced by funded defined contribution schemes, then the latter would in principle be more portable, even if they involved different national contribution rates, if they satisfied certain basic requirements. As argued above, however, the trend that is now developing in Europe toward funded pensions is not likely to eliminate PAYG schemes completely. There will remain a need for providing a minimum level of benefits, not linked to an individual's contributions. This suggests a "two pillars" approach, in which the first pillar would involve basic benefits provided by the EU and financed by either EU budgetary revenues or a special EU contribution. Such a scheme would avoid the problem of tax competition producing inadequate revenues to finance minimum social benefits, while allowing different national preferences on the extent of additional benefits to be implemented in the "second pillar," which would be provided by funded, national schemes, subject to some standardization imposed by EU regulations. This standardization would aim to make pensions provided by the second pillar portable, so they would not distort employment decisions or be a barrier to labor mobility.

Progress on social security reform leading to greater harmonization across the EU presupposes some consensus on the desirable extent of social security and the way in which current PAYG schemes are to be made solvent. However, there is likely to be considerably greater agreement on the need for, and the level of, minimum social benefits than on other aspects of reform, so that a scheme that allows diversity in those other aspects is more likely to be implemented. Also, its design should attempt to enhance mobility by standardizing benefits without producing large net flows between countries. For funded pensions, this would not be a problem, but for the basic pension, if benefit levels were high, differences in income levels would lead to net flows. The accession to the EU of new members, with lower per capita incomes, could exacerbate this problem, 
while differences in demographic profiles (as is the case for instance, when Spain is compared to her northern neighbors) would also produce substantially different revenues and disbursements if benefit levels were high. Thus it is likely that minimum social benefits would be relatively low, at least initially.

A more serious obstacle to reform is reflected in fundamental differences of view on the benefits and costs of competition. In some countries competition among social security systems is considered a good thing precisely because it will shrink them, while the view in others is that the level of benefits ("les acquis sociaux") needs to be defended at all costs. Even within some countries (such as Belgium), the extent of regional redistribution within the national social security system is a source of contention, and there are calls for regionalization of social security. Thus, the extension of EU fiscal powers into this area is unlikely to occur without considerable conflict and soul-searching, even though the logic of integration may push in that direction in the longer term. Pressures for harmonization of social security may only occur after there has been sufficient mobility to make problems evident. However, if non-portability of benefits constitutes a serious barrier to mobility, these pressures may never develop, and Europe may get stuck in a low mobility, low growth equilibrium. 


\section{CONCLUDING REMARKS}

Coordination of fiscal policies will be a major issue within the euro zone and the EU for the foreseeable future. In the absence of coordination, there will be pressures from tax competition to limit the level of services provided by governments. Coordination can result from inter-governmental agreements to harmonize taxes and benefits, from a European wide fiscal policy, or from surveillance and peer pressure on fiscal policies. Though harmonization has occurred in a number of specific areas, resistance to harmonizing taxes on non-labor income or spending policies is likely to continue. Stable systems that can dependably rule out the worst outcomes from uncoordinated policies are likely to involve the development of EU-wide fiscal policies. However, agreement on what such a fiscal policy should involve seems distant at this point in time.

Endogenous growth theory points to a few areas where externalities might suggest that EU-wide policies would be desirable, in particular, in order to stimulate knowledge-creating activities and factor mobility. However, it does not imply a clear need to expand EU-wide stabilization or redistribution, neither of which seems to stimulate growth. Moreover, by helping to create a single market for goods and factors, the euro will tend to increase flexibility of goods and factor prices and eliminate credit market distortions, reducing the need for government intervention to counter shocks. Evidence reported in Bayoumi and Masson (1995) that EU governments performed as much (or as little) stabilization as US states or Canadian provinces provides some support for this position. Over time, there may be some gradual increase in the taxing power at the EU level, accompanied by reductions in fiscal responsibilities of national governments. The above suggests that the EU should concentrate on encouraging economies of scale not exploited by single countries (e.g. transportation or information networks), on stimulating knowledge-based activities that may have European-wide externalities (R\&D), and on reducing obstacles to labor mobility by harmonizing some elements of social security. 
Table 1 - Selected Industrial Countries: General Government Revenues and Expenditures (percent of GDP)

\begin{tabular}{|l|cc|cc|}
\hline & \multicolumn{2}{|c|}{ Revenues } & \multicolumn{2}{c|}{ Expenditures } \\
& 1998 & 1999 & 1998 & 1999 \\
\hline Country & & & & \\
$\quad$ European Union & & & & \\
Austria & 51.7 & 51.7 & 54.2 & 54.0 \\
Belgium & 46.4 & 46.3 & 47.5 & 47.1 \\
Denmark & 56.8 & 58.1 & 55.9 & 55.3 \\
Finland & 51.1 & 51.2 & 49.8 & 48.2 \\
France & 51.5 & 51.9 & 54.2 & 53.9 \\
Germany & 46.6 & 47.3 & 48.3 & 48.5 \\
Greece & 47.1 & 47.4 & 49.6 & 49.1 \\
Ireland & 34.1 & 34.1 & 32.0 & 30.9 \\
Italy & 46.5 & 46.8 & 49.2 & 48.8 \\
Luxembourg & 44.9 & 46.2 & 42.3 & 43.9 \\
Netherlands & 44.3 & 45.5 & 45.1 & 45.3 \\
Portugal & 43.4 & 45.0 & 45.5 & 46.7 \\
Spain & 40.2 & 39.8 & 41.9 & 41.1 \\
Sweden & 60.5 & 60.2 & 58.4 & 58.5 \\
United Kingdom $\quad 38.7$ & 39.0 & 38.5 & 38.6 \\
$\quad$ average & 46.9 & 47.4 & 47.5 & 47.3 \\
Other European Countries & & & & \\
Iceland & 37.0 & 35.4 & 36.6 & 34.6 \\
Malta & 33.3 & 34.8 & 43.7 & 43.4 \\
Norway & 50.4 & 50.2 & 46.5 & 45.6 \\
Switzerland & 38.2 & 37.2 & 39.3 & 39.1 \\
Turkey $\quad$ Other Industrial Countries & 24.0 & 24.8 & 34.8 & 41.2 \\
Australia & & & & \\
Canada & 33.1 & 33.2 & 32.9 & 32.9 \\
Japan & 48.3 & 47.6 & 47.4 & 45.4 \\
New Zealand & 31.9 & 30.6 & 36.2 & 37.8 \\
United States & 37.5 & 36.1 & 35.1 & 35.1 \\
& 29.9 & 30.1 & 30.0 & 29.6 \\
\hline
\end{tabular}

Source: World Economic Outlook database. 
Table 2 - EU Budget for 1999

\begin{tabular}{lcc}
\hline & Billions of euro & Percent of EU GDP \\
\hline Total commitment appropriations & & 1.25 \\
Of which: & 96.93 & Percent of total \\
$\quad$ Agriculture & 40.94 & 42.2 \\
$\quad$ Structural operations & 39.26 & 40.5 \\
$\quad$ External action & 6.22 & 6.4 \\
$\quad$ Administrative expenditure & 4.50 & 4.6 \\
Research and technology & 3.45 & 3.6 \\
Other & 2.56 & 2.6 \\
& & Percent of EU GDP \\
Total revenues (equals total payment & 85.56 & 1.10 \\
appropriations) & & \\
Of which: & & Percent of total \\
$\quad$ GNP-based contributions & 39.26 & 45.9 \\
$\quad$ VAT & 30.37 & 35.5 \\
Customs duties & 11.89 & 13.9 \\
Other & 4.04 & 4.7 \\
\hline
\end{tabular}

Source: European Commission (1999). 
Table 3 - Real GDP Growth and Stabilization Policy, 1960-98 ${ }^{1}$

\begin{tabular}{lccc}
\hline & Average rate of growth g & Standard deviation $\sigma$ & $\begin{array}{c}\text { Slope coefficient b: } \\
\text { DEF/PY=a+b(Y/YBAR) }\end{array}$ \\
\hline Austria ${ }^{2}$ & $3.15 \%$ & $2.11 \%$ & 0.172 \\
Belgium & $3.27 \%$ & $2.07 \%$ & $0.501^{*}$ \\
Denmark & $2.86 \%$ & $2.30 \%$ & $1.119^{*}$ \\
Finland & $3.34 \%$ & $3.05 \%$ & $0.566^{*}$ \\
France & $3.31 \%$ & $2.06 \%$ & 0.197 \\
Germany & $2.87 \%$ & $2.18 \%$ & 0.038 \\
Greece & $4.09 \%$ & $3.57 \%$ & -0.249 \\
Ireland & $4.70 \%$ & $2.52 \%$ & -0.203 \\
Italy & $3.50 \%$ & $2.87 \%$ & -0.597 \\
Luxembourg & $3.12 \%$ & $2.69 \%$ & $0.185^{*}$ \\
Netherlands & $3.80 \%$ & $5.10 \%$ & 0.069 \\
Portugal & $3.73 \%$ & $3.36 \%$ & $0.606^{*}$ \\
Spain & $4.16 \%$ & $3.00 \%$ & $0.307^{*}$ \\
Sweden & $2.50 \%$ & $2.17 \%$ & $1.150^{*}$ \\
U.K & $2.43 \%$ & $2.05 \%$ & $0.471^{*}$ \\
& & correlation between & Correlation between \\
& & $g$ and $\sigma=0.506$ & g and b=-0.554 \\
\hline
\end{tabular}

1 Source: IMF, International Financial Statistics and World Economic Outlook database. Time period is shorter when full data sample did not exist. Regression of the general government deficit as a ratio to nominal GDP (DEF/PY) on the output gap (Y/YBAR) used instrumental variables, with two lags of the lagged output gap and of real GDP growth as instruments. The output gap is actual GDP divided by GDP smoothed using a Hodrick-Prescott filter, with value of lambda $=1000$. For Germany, pre-unification data were scaled up to make them comparable.

2 Growth rate and standard deviation calculated for 1964-98.

3 Growth rate and standard deviation calculated for 1969-98.

* Significant at the 10 percent level. 
Table 4 - Social Benefit Spending (s) and Subsequent Growth (g) in the EU

(as percent of GDP and as percent, respectively)

\begin{tabular}{|c|c|c|c|c|c|c|}
\hline & $\begin{array}{c}\text { Total social } \\
\text { benefits, } \\
1985\end{array}$ & $\begin{array}{l}\text { GDP growth } \\
\text { rate,1986-98 }\end{array}$ & $\begin{array}{c}\text { Total social } \\
\text { benefits, } \\
1990\end{array}$ & $\begin{array}{l}\text { GDP growth } \\
\text { rate,1991-98 }\end{array}$ & $\begin{array}{c}\text { Total social } \\
\text { benefits, } \\
1993\end{array}$ & $\begin{array}{l}\text { GDP growth } \\
\text { rate,1994-98 }\end{array}$ \\
\hline Austria & 26.4 & $2.54 \%$ & 25.9 & $2.14 \%$ & 28.1 & $2.36 \%$ \\
\hline Belgium & 26.9 & $2.50 \%$ & 25.4 & $2.23 \%$ & 27.3 & $1.54 \%$ \\
\hline Denmark & 27 & $2.17 \%$ & 29.4 & $2.70 \%$ & 32.6 & $3.62 \%$ \\
\hline Finland & & $2.28 \%$ & 24.6 & $1.65 \%$ & 34.5 & $4.58 \%$ \\
\hline France & 27.3 & $2.14 \%$ & 26.4 & $1.47 \%$ & 29.5 & $2.23 \%$ \\
\hline Germany & 25.6 & $2.42 \%$ & 24.4 & $1.83 \%$ & 28 & $1.69 \%$ \\
\hline Greece & & $1.88 \%$ & 21.3 & $1.98 \%$ & 21 & $2.57 \%$ \\
\hline Ireland & 22.9 & $5.92 \%$ & 18.2 & $6.30 \%$ & 19.9 & $8.53 \%$ \\
\hline Italy & 21.4 & $1.90 \%$ & 22.9 & $1.26 \%$ & 24.7 & $1.76 \%$ \\
\hline Luxembourg & 23.2 & $3.44 \%$ & 22.6 & $2.68 \%$ & 24.3 & $3.15 \%$ \\
\hline Netherlands & 30.6 & $2.81 \%$ & 31 & $2.61 \%$ & 32 & $3.20 \%$ \\
\hline Portugal & & $3.57 \%$ & 13.6 & $2.29 \%$ & 18.2 & $3.09 \%$ \\
\hline Spain & 19 & $3.00 \%$ & 19.9 & $2.06 \%$ & 23.8 & $2.94 \%$ \\
\hline Sweden & & $1.49 \%$ & & $0.98 \%$ & 38 & $2.64 \%$ \\
\hline U.K & & $2.54 \%$ & 22.1 & $2.05 \%$ & 27.7 & $3.10 \%$ \\
\hline $\begin{array}{l}\text { correlation } \\
\text { between } \mathrm{s} \text { and } \mathrm{g}\end{array}$ & & -0.271 & & -0.260 & & -0.210 \\
\hline
\end{tabular}

Source for social benefits data: Eurostat (1999) 
Table 5 - Pension Systems in the EU

\begin{tabular}{l|ccc}
\hline \multicolumn{1}{c|}{ Country } & $\begin{array}{c}\text { Public pension } \\
\text { benefits as percent } \\
\text { of GDP }\end{array}$ & $\begin{array}{c}\text { Gross } \\
\text { replacement } \\
\text { ratio of public } \\
\text { pensions }\end{array}$ & $\begin{array}{c}\text { Private pension funds } \\
\text { (percent of GDP) }\end{array}$ \\
\hline Austria & 14 & 70 & 1.1 \\
Belgium & 12 & 45 & 4.3 \\
Denmark & 13 & 37 & 22.2 \\
Finland & 10 & 59 & 14.4 \\
France & 13 & 51 & 4.5 \\
Germany & 12 & 43 & 5.8 \\
Greece & n.a. & 48 & 2.8 \\
Ireland & 5 & 21 & 43.3 \\
Italy & 15 & 75 & 2.5 \\
Luxembourg & 11 & 76 & 0.2 \\
Netherlands & 11 & 31 & 88.9 \\
Portugal & 8 & 74 & 10.7 \\
Spain & 10 & 63 & 4.1 \\
Sweden & 13 & 50 & 32.7 \\
United Kingdom & 10 & 14 & 75.6 \\
$\quad$ EU Average & 12 & 50.5 & 20.9 \\
Canada & & n.a. & 45.4 \\
Japan & & n.a. & 21.8 \\
United States & & 45 & 62.4 \\
\hline
\end{tabular}

Source: Boldrin et al. (1999), Davis (1998), Tables 2 and 7. As percent, based on \$50,000 salary in 1997 . 


\section{Appendix Table - Instrumental Variables Regressions ${ }^{1}$ DEF/PY $=a+b(Y / Y B A R)$}

(absolute t-ratios in parentheses)

\begin{tabular}{|c|c|c|c|c|c|}
\hline Country & Intercept & Slope & R-squared & Durbin-Watson & Time period \\
\hline Austria & $\begin{array}{l}-0.210 \\
(1.31)\end{array}$ & $\begin{array}{c}0.172 \\
(1.08)\end{array}$ & 0.085 & 0.351 & $67-98$ \\
\hline Belgium & $\begin{array}{l}-0.556 \\
(2.10)\end{array}$ & $\begin{array}{c}0.501 \\
(1.89)\end{array}$ & 0.137 & 0.162 & $63-98$ \\
\hline Denmark & $\begin{array}{l}-1.122 \\
(4.03)\end{array}$ & $\begin{array}{c}1.119 \\
(4.02)\end{array}$ & 0.294 & 0.610 & $63-98$ \\
\hline Finland & $\begin{array}{l}-0.590 \\
(3.67)\end{array}$ & $\begin{array}{c}0.566 \\
(3.52)\end{array}$ & 0.306 & 0.313 & $63-98$ \\
\hline France & $\begin{array}{l}-0.216 \\
(1.28)\end{array}$ & $\begin{array}{c}0.197 \\
(1.17)\end{array}$ & 0.102 & 0.455 & $63-98$ \\
\hline Germany & $\begin{array}{l}-0.051 \\
(0.56)\end{array}$ & $\begin{array}{c}0.038 \\
(0.42)\end{array}$ & 0.029 & 0.572 & $63-98$ \\
\hline Greece & $\begin{array}{c}0.183 \\
(0.54)\end{array}$ & $\begin{array}{l}-0.249 \\
(0.73)\end{array}$ & -0.037 & 0.407 & $63-98$ \\
\hline Ireland & $\begin{array}{c}0.136 \\
(0.615)\end{array}$ & $\begin{array}{l}-0.203 \\
(0.92)\end{array}$ & -0.029 & 0.144 & $63-98$ \\
\hline Italy & $\begin{array}{c}0.512 \\
(1.18)\end{array}$ & $\begin{array}{l}-0.597 \\
(1.37)\end{array}$ & -0.042 & 0.506 & $63-98$ \\
\hline Luxembourg & $\begin{array}{l}-0.150 \\
(1.18)\end{array}$ & $\begin{array}{c}0.185 \\
(1.45)\end{array}$ & 0.110 & 0.686 & $65-98$ \\
\hline Netherlands & $\begin{array}{l}-0.097 \\
(1.25)\end{array}$ & $\begin{array}{c}0.069 \\
(0.88)\end{array}$ & 0.079 & 0.440 & $63-98$ \\
\hline Portugal & $\begin{array}{l}-0.679 \\
(3.46)\end{array}$ & $\begin{array}{c}0.606 \\
(3.10)\end{array}$ & 0.347 & 0.792 & $72-98$ \\
\hline Spain & $\begin{array}{l}-0.338 \\
(3.69)\end{array}$ & $\begin{array}{c}0.307 \\
(3.35)\end{array}$ & 0.309 & 0.553 & $63-98$ \\
\hline Sweden & $\begin{array}{l}-1.185 \\
(3.73)\end{array}$ & $\begin{array}{r}1.150 \\
(3.62)\end{array}$ & 0.383 & 0.757 & $63-98$ \\
\hline United Kingdom & $\begin{array}{l}-0.495 \\
(2.57)\end{array}$ & $\begin{array}{c}0.471 \\
(2.45)\end{array}$ & 0.126 & 0.430 & $63-98$ \\
\hline
\end{tabular}

Source: IMF, International Financial Statistics and World Economic Outlook database. Time period is shorter when full data sample did not exist. Regression of the general government deficit as a ratio to nominal GDP (DEF/PY) on the output gap (Y/YBAR) used instrumental variables, with two lags of the lagged output gap and of real GDP growth as instruments. The output gap is actual GDP divided by GDP smoothed using a Hodrick-Prescott filter, with value of lambda $=1000$. For Germany, pre-unification data were scaled up to make them comparable. 


\section{References}

Acs, Zoltan, John de la Mothe, and Gilles Paquet (1996), "Local Systems of Innovation: In Search of an Enabling Strategy," in P. Howitt, ed., The Implications of Knowledge-Based Growth for Micro-Economic Policies, Industry Canada Research Series (Calgary: University of Calgary Press), pp. 339-59.

Aghion, Philippe, Eve Caroli, and Cecilia Garcia-Penalosa (1999), "Inequality and Economic Growth: The Perspective of the New Growth Theories," Journal of Economic Literature, Vol. 37 (December), pp. 1615-60.

Aghion, Philippe and Peter Howitt (1998), Endogenous Growth Theory (Cambridge, MA: MIT Press).

Aschauer, David (1989), "Is Productive Expenditure Productive?" Journal of Monetary Economics (March).

Barro, Robert (1991), "Economic Growth in a Cross Section of Countries," Quarterly Journal of Economics, Vol. 106 (May), pp. 407-443.

Barro, Robert, and Xavier Sala-i-Martin (1992), "Public Finance in Models of Economic Growth," Review of Economic Studies Vol. 59 (October), pp. 645-61.

Bayoumi, Tamim and Paul Masson (1995), "Fiscal Flows in the United States and Canada: Lessons for Monetary Union in Europe," European Economic Review, Vol. 39, pp. 253-74.

(1998), "Liability-creating versus Non-liability-creating Fiscal Stabilisation Policies: Ricardian Equivalence, Fiscal Stabilisation and EMU," The Economic Journal, Vol. 108 (July), pp. 1026-45.

Benabou, Roland (1996), "Inequality and Growth," in B.S. Bernanke and J. Rotemberg, eds., NBER Macroeconomics Annual, Vol. 11 (Cambridge, MA: MIT Press).

Boadway, Robin (1996), "Comment on John Whalley, Interprovincial Barriers to Trade and Endogenous Growth Considerations," in P. Howitt, ed., The Implications of KnowledgeBased Growth for Micro-Economic Policies, Industry Canada Research Series (Calgary: University of Calgary Press), pp. 178-85.

Boldrin, Michele, Juan Dolado, Juan Jimeno, and Franco Penacchi (1999), "The Future of Pensions in Europe," Economic Policy 29 (October), pp. 289-320.

Bottazzi, Laura, and Giovanni Peri (1999), "Innovation, Demand and Knowledge Spillovers: Theory and Evidence from European Regions," CEPR Discussion Paper 2279 (London: Centre for Economic Policy Research).

Bryant, Ralph (1995), International Coordination of National Stabilization Policies (Washington, DC: Brookings).

Buchanan, James and Richard Musgrave (1999), Public Finance and Public Choice: Two Contrasting Visions of the State (Cambridge, MA: MIT Press). 
Cohen, Daniel, and Charles Wyplosz (1989), "The European Monetary Union: An Agnostic Evaluation," in R.C. Bryant, D.A. Currie, J.A. Frenkel, P.R. Masson, and R. Portes, eds., Macroeconomic Policies in an Interdependent World (Washington, DC: International Monetary Fund), pp. 311-37.

Courchene, Thomas (1993), "Reflections on Canadian Federalism: Are There Implications for European Economic and Monetary Union?" European Economy, Reports and Studies No. 5: The Economics of Community Public Finance, pp. 123-66.

Crafts, Nicholas (2000), "Globalization and Growth in the Twentieth Century," IMF Working Paper WP/00/44 (Washington, DC: International Monetary Fund).

Dantec, Alexis, and Florian Pelgrin (1998), "Retraites de l'Europe," Revue de l'OFCE, no. 67 (October),

pp. 207-28.

Davis, E. Philip (1998), "Pension Fund Reform and European Financial Markets," Special Paper No. 107, Financial Markets Group, London School of Economics.

De Long, Bradford, and Lawrence Summers (1991), "Equipment Investment and Economic Growth," Quarterly Journal of Economics, Vol. 106 (May), pp. 445-502.

Easterly, William, and Sergio Rebelo (1993), "Fiscal Policy and Economic Growth: An Empirical Investigation," Journal of Monetary Economics, Vol. 32 (December), pp. 417-58.

Eichengreen, Barry (1992), "Designing a Central Bank for Europe: A Cautionary Tale from the Early Years of the Federal Reserve System," in M. Canzoneri, V. Grilli, and P. Masson, eds., Establishing a Central Bank: Issues in Europe and Lessons from the US (Cambridge: Cambridge University Press), pp. 13-40.

European Commission (1999), General Budget of the European Union for the Financial Year 1999 (Luxembourg: Office for Official Publications of the European Communities).

Eurostat (1999), Social Protection Expenditure and Receipts: European Union, Iceland and Norway (Luxembourg: Office for Official Publications of the European Communities).

Fatás, Antonio and Ilian Mihov (1999), "Government Size and Automatic Stabilizers: International and Intranational Evidence," CEPR Discussion Paper 2259 (London: Centre for Economic Policy Research).

Frankel, M. (1962), "The Production Function in Allocation and Growth: A Synthesis," American Economic Review, Vol. 52, pp. 995-1022.

Goodhart, Charles (1996), "European Monetary Integration," European Economic Review, Vol. 40 (April), pp. 1083-90.

Grossman, Gene, and Elhanan Helpman (1991), Innovation and Growth in the Global Economy (Cambridge, MA: MIT Press).

Harris, Richard (1996), "Evidence and Debate on Economic Integration and Economic Growth," in P. Howitt, ed., The Implications of Knowledge-Based Growth for MicroEconomic Policies, Industry Canada Research Series (Calgary: University of Calgary Press), pp. 119-62. 
Helpman, Elhanan, and M. Trajtenberg (1994), "A Time to Sow and a Time to Reap: Growth Based on General Purpose Technologies," CEPR Discussion Paper 1080 (London: Centre for Economic Policy Research).

Kollintzas, Tryphon, Apostolis Phillippopoulos, and Vanghelis Vassilatos (1999), "Normative Aspects of Fiscal Policy in an Economic Union: A Review," CEPR Discussion Paper 2212 (London: Centre for Economic Policy Research).

Lipsey, Richard, and Ken Carlaw (1996), "A Structuralist View of Innovation Policy," in P. Howitt, ed., The Implications of Knowledge-Based Growth for Micro-Economic Policies, Industry Canada Research Series (Calgary: University of Calgary Press), pp. 255-333.

Lucas, Robert E. (1988), "On the Mechanics of Economic Development," Journal of Monetary Economics, Vol. 22(1), pp. 3-42.

(1993), "Making a Miracle," Econometrica, Vol. 61, pp. 251-72.

Mansfield, Edwin (1996), "Microeconomic Policy and Technological Change," in J.C. Fuhrer and J.S. Little, eds., Technology and Growth, Conference Series No. 40 (Boston: Federal Reserve Bank of Boston), pp. 183-200.

Melitz, Jacques, and Silvia Vori (1992), "National Insurance against Unevenly Distributed Shocks," CEPR Discussion Paper 697 (London: Centre for Economic Policy Research).

Mendoza, Enrique, Gian Maria Milesi-Ferretti, and Patrick Asea (1997), "On the Ineffectiveness of Tax Policy in Altering Long-Run Growth: Harberger's Superneutrality Conjecture," Journal of Public Economics, Vol. 66, pp. 99-126.

Miles, David, and Allan Timmermann (1999), "Risk Sharing and Transition Costs in the Reform of Pension Systems in Europe," Economic Policy 29 (October), pp. 253-86.

Oates, Warren (1972), Fiscal Federalism (New York: Harcourt Brace Jovanovich).

Persson, Torsten, and Guido Tabellini (1996), "Federal Fiscal Constitutions: Risk Sharing and Redistribution," Journal of Political Economy, Vol. 104, pp. 979-1009.

Pieters, D., and S. Vansteenkiste (1993), The Thirteenth State: Towards a Social Security Scheme for Intra-Community Migrants (Leuven: Maklu).

Pisani-Ferry, Jean, Alexander Italianer, and R. Lescure (1993), "Stabilization Properties of Budgetary Systems," European Economy: The Economics of Community Public Finance, Reports and Studies, Vol. 5, pp. 511-38.

Romer, Paul M. (1986), "Increasing Returns and Long Run Growth," Journal of Political Economy, Vol. 94(5), pp. 1002-37.

Solow, Robert (1956), "A Contribution to the Theory of Economic Growth," Quarterly Journal of Economics, Vol. 70 (1), pp. 65-94.

Talvi, Ernesto and Carlos Végh (2000), "Tax Base Variability and Procyclical Fiscal Policy," NBER Working Paper 7499 (Cambridge, MA: National Bureau of Economic Research).

Tanzi, Vito (2000), "Globalization and the Future of Social Protection," IMF Working Paper WP/00/12 (Washington, DC: International Monetary Fund). 
Tanzi, Vito, and Howell Zee (1997), "Fiscal Policy and Long-Run Growth," IMF Staff Papers, Vol 44 (June), pp. 179-209.

Temple, Jonathan (1999), "Why Do Growth Rates Differ?" Journal of Economic Literature, Vol. 37 (March), pp. 112-56.

Tiebout, Charles (1956), "A Pure Theory of Local Expenditures," Journal of Political Economy, Vol. 64, pp. 416-24.

Vansteenkiste, Steven (1998), "Social Security in the European Community: Towards a Federal Style Division of Competencies?" in D. Pieters, ed., Social Protection of the Next Generation (The Hague: Kluwer Law International), pp. 251-76.

Von Hagen, Jürgen, and George Hammond (1997), "Insurance Against Asymetric Shocks in a European Monetary Union," in J.-O. Hairault, P.-Y. Hénin, and F. Portier, eds., Business Cycles and Macroeconomic Stability: Should We Rebuild Built-in Stabilisers? (Boston: Kluwer Academic Publishers), pp. 171-88.

Walsh, Cliff (1993), "Fiscal Federalism: An Overview of Issues and a Discussion of Their Relevance to the European Community," European Economy, Reports and Studies No. 5: The Economics of Community Public Finance, pp. 25-62. 


\section{NATIONAL BANK OF BELGIUM - WORKING PAPERS SERIES}

1. "Model-based inflation forecasts and monetary policy rules" by M. Dombrecht and R. Wouters, Research Series, March 2000

2. "The use of robust estimators as measures of core inflation" by L. Aucremanne, Research Series, March 2000

3. "Performances économiques des Etats-Unis dans les années nonante" by A. Nyssens, P. Butzen, P. Bisciari, Document Series, March 2000.

4. "A model with explicit expectations for Belgium" by P. Jeanfils, Research Series, March 2000.

5. "Growth in an open economy: some recent developments" by S. Turnovsky, Research Series, May 2000

6. "Knowledge, technology and economic growth: an OECD perspective" by I. Visco, Research Series, May 2000

7. "Fiscal policy and growth in the context of European integration" by P. Masson, Research Series, May 2000

8. "The role of the labour market" by C. Wyplosz, Research Series, May 2000

9. "The role of the exchange rate in economic growth" by R. MacDonald, Research Series, May 2000

10. "Economic growth and monetary union" by J. Vickers, Research Series, May 2000 